\title{
Layanan Kesehatan Bagi Lansia
}

Oleh: Arella Kartikaputri

Email: arellaptr@gmail.com

Indonesia adalah negara terpadat ketiga di Asia dan merupakan masyarakat yang menua dengan cepat. Badan Pusat Statistik memperkirakan jumlah penduduk lanjut usia akan meningkat dari 20,24 juta pada tahun 2014 menjadi 36 juta pada tahun 2025 (Badan Pusat Statistik, 2015), sedangkan Perserikatan Bangsa-Bangsa (PBB) memperkirakan bahwa jumlahnya akan mencapai 25\% dari jumlah penduduk pada tahun 2050 atau hampir 4 kali lebih tinggi dari tahun 2014 (UN, 2015). Melalui Peraturan No. 25/2016, negara meluncurkan Rencana Strategis Nasional untuk lansia, yang menjadikan Puskesmas, sebuah klinik yang didanai negara, sebagai penyedia layanan kesehatan garis depan dan LTC. Di tingkat akar rumput, pemerintah mendorong masyarakat setempat untuk menggalakkan Pos Pelayanan Terpadu (Posyandu). Layanan ini pada awalnya bertujuan untuk mengidentifikasi gizi buruk dan masalah kesehatan lainnya dengan melibatkan relawan dalam melakukan pemeriksaan bulanan dan penyuluhan kesehatan. Dengan demikian, penyediaan LTC dan pemenuhan kebutuhan lansia telah menjadi kewajiban pemerintah setelah ICESCR diratifikasi.

Di Kota Surabaya terdapat 19 Posyandu per mil persegi dan enam Posyandu per mil persegi di Kota Malang. Di perdesaan Kabupaten Malang, terdapat dua posyandu yang masing-masing satu mil persegi, artinya satu posyandu memberikan pelayanan kepada empat lansia. Gambar tersebut menunjukkan wilayah cakupan yang lebih luas di pedesaan daripada di wilayah perkotaan, yang mungkin menyiratkan aksesibilitas yang lebih rendah. Sebagian besar keluarga di Kota Malang mengandalkan kegiatan bertani dan mereka menghabiskan lebih banyak waktu dengan anggota keluarga yang lebih tua. Transportasi yang tidak memadai menjadi hambatan yang signifikan bagi aksesibilitas di daerah pedesaan. Kondisi jalan raya sangat parah, terutama pada musim hujan. Posyandu tersedia di pusat desa, tetapi wawancara menunjukkan bahwa penggunaan layanannya terhambat oleh kurangnya transportasi, masalah kesehatan, dan masalah keluarga, seperti yang diungkapkan oleh beberapa responden lansia.

Di Amerika, Urinary Incontinence(UI) adalah masalah yang mempengaruhi lebih dari 16 juta orang, kebanyakan dari mereka adalah wanita. Meskipun hampir setengah dari lansia di Amerika mengalami episode UI, ini bukanlah konsekuensi normal dari penuaan. Ini tetap menjadi masalah yang sebagian besar terabaikan meskipun prevalensi, morbiditas, dan biaya yang cukup besar. Artikel ini melaporkan proses penyaringan risiko kesehatan proaktif yang berhasil untuk mengatasi masalah utama ini. (Dash, Foster, Smith, Phillips, 2004) 
Hasil pengamatan dan wawancara yang sudah saya lakukan kepada kakek kerabat saya bernama Soeyoto usia 78 pendidikan terakhir SMA tinggal di kota Kediri bersama anak dan cucu tersayang nya. Beliau mengalami masalah kesehatan gula darah, serta mendapatkan layanan kesehatan tiap minggu melalui acara desa yang memberikan layanan kesehatan bagi lansia. Namun, sayangnya layanan tersebut sudah dihentikan semenjak masa pandemi ini guna meminimalisir penyebaran virus Covid 19. Disekitar rumah beliau tepatnya di Desa, terdapat sebuah posyandu yang tak jauh tempatnya, hal tersebut sudah sesuai dengan prinsip-prinsip yang terdapat dalam artikel (Pratono \& Maharani, 2018). 


\section{REFERENCES}

City Government of Malang. (2013, January 15). Performance Accountability Report (LAKIP). Retrieved from https://dinkes.malangkota.go.id/wp-content/uploads/ sites/104/2016/03/Laporan-Kinerja-Tahunan-Dinas-Kesehatan-Kota-Malang- Tahun-2015.pdf

City Government of Surabaya. (2011, January 17). Food assistance program for elderly. Retrieved from http://dinkes.surabaya.go.id/portal/berita/anggaran-pmt- lansia-meningkat-empatkali/

Dash, M.E., Foster, B.E., Smith, D.M., Phillips, S.L. (2004). Urinary incontinence: The social health maintenance organization's approach (CE). Geratric Nursing, 25, 2, 81-89.

Pratono, A.H., Maharani, A. (2018). Long-Term Care in Indonesia: The Role of integrated Service Post for Elderly. Journal of Aging and Health, 30(10), 1556-1573.

Statistics Indonesia. (2015). Aging Statistics Indonesia 2014. Jakarta, Indonesia: National Statistics Indonesia. 